\title{
EFFECT OF FUEL THERMAL PRETREAMENT ON THE ELECTROCHEMICAL PERFORMANCE OF A DIRECT LIGNITE COAL FUEL CELL
}

\author{
N. Kaklidis ${ }^{1}$, V. Kyriakou ${ }^{2,3, *}$, G.E. Marnellos ${ }^{1,3,4}$, R. Strandbakke ${ }^{5}$, A. Arenillas ${ }^{6}$, J.A. \\ Menéndez $^{6}$, M. Konsolakis ${ }^{7}$
}

${ }^{1}$ Department of Mechanical Engineering, University of Western Macedonia, 50100 Kozani, Greece

${ }^{2}$ Department of Chemical Engineering, Aristotle University of Thessaloniki, Building E13, 54124 Thessaloniki, Greece

${ }^{3}$ Chemical Process \& Energy Resources Institute, Centre for Research \& Technology Hellas, 57001 Thermi, Thessaloniki, Greece

${ }^{4}$ Department of Environmental Engineering, University of Western Macedonia, 50100 Kozani, Greece

${ }^{5}$ Department of Chemistry, Centre for Materials Science and Nanotechnology, University of Oslo, FERMiO, Gaustadalleen 21, NO-0349 Oslo, Norway

${ }^{6}$ Instituto Nacional del Carbon, Apartado 73, 33080 Oviedo, Spain

${ }^{7}$ School of Production Engineering and Management, Technical University of Crete, GR-73100 Chania, Crete, Greece

To whom correspondence should be addressed

*Corresponding author. Tel.: 00302310996145 ; E-mail: kyriakou@cperi.certh.gr 


\begin{abstract}
The impact of fuel heat pretreatment on the performance of a Direct Carbon Fuel Cell (DCFC) is investigated by utilizing Lignite (LG) coal as feedstock in a solid oxide fuel cell of the type: lignite $\left|\mathrm{Co}-\mathrm{CeO}_{2} / \mathrm{YSZ} / \mathrm{Ag}\right|$ air. Four LG samples are employed as feedstock: (i) pristine lignite (LG), and differently heat treated LG samples under inert (He) atmosphere at (ii) $200{ }^{\circ} \mathrm{C}$ overnight (LG200), (iii) $500{ }^{\circ} \mathrm{C}$ for $1 \mathrm{~h}$ (LG500) and (iv) $800{ }^{\circ} \mathrm{C}$ for $1 \mathrm{~h}$ (LG800). The impact of several process parameters, related to cell temperature $\left(700-800{ }^{\circ} \mathrm{C}\right)$, carrier gas type $\left(\mathrm{He}\right.$ or $\left.\mathrm{CO}_{2}\right)$, and molten carbonates infusion into the feedstock on the DCFC performance is additionally explored. The proximate and ultimate analysis of the original and pretreated lignite samples show that upon increasing the heat treatment temperature the carbon content is monotonically increased, whereas the volatile matter, moisture, sulfur and oxygen contents are decreased. In addition, although volatiles are eliminated upon increasing the treatment temperature and as a consequence more ordered carbonaceous structure is remained, the degree of heat treatment increases the reactivity of lignite towards $\mathrm{CO}_{2}$ due mainly to the increased carbon content. These modifications are reflected on the achieved DCFC performance, which is clearly improved upon increasing the treatment temperature. An inferior cell performance is demonstrated by utilizing inert $\mathrm{He}$ instead of reactive $\mathrm{CO}_{2}$ atmosphere, as purging gas in anode compartment, while carbonates infusion always result in ca. $70-100 \%$ increase in power output $\left(15.1 \mathrm{~mW} \cdot \mathrm{cm}^{-2}\right.$ at $\left.800{ }^{\circ} \mathrm{C}\right)$. The obtained findings are discussed based also on AC impedance spectroscopy measurements, which revealed the impact of LG physicochemical characteristics and DCFC operating parameters on both ohmic and electrode resistances.
\end{abstract}

Keywords: Direct Carbon Fuel Cell; lignite fuel; $\mathrm{Co} / \mathrm{CeO}_{2}$ anode; carbonates; heat treatment 


\section{INTRODUCTION}

Nowadays, coal is by far the most abundant natural resource, accounted for more than $30 \%$ of the global energy consumption [1]. However, the energy conversion of carbon is principally carried out in coal-fired plants, resulting in low conversion efficiencies and high emissions of environmentally harmful gases. Hence, the elaboration of novel technologies for efficient and clean coal energy production is of vital importance toward a sustainable energy economy [2-9].

A direct carbon fuel cell (DCFC) is the only electrochemical device in which the chemical energy of solid carbonaceous feedstock can be directly converted to electricity at efficiencies much higher than those thermodynamically predicted in common heat cycles [4]. More specifically, DCFCs have several advantages, as compared to conventional power plants and gas-fuelled Solid Oxide Fuels Cells (SOFCs) [6-8], involving the extremely high theoretical efficiency ( $\sim 100 \%)$, the easy capture and sequestration of $\mathrm{CO}_{2}$ emissions as well as the abundance and variety of carbon-based fuels [69].

In DCFCs based on SOFC configuration, the electrochemical oxidation of carbon is taking place via the reactions (1) and (2), which are standing for carbon complete and partial electro-oxidation by oxygen anions $\left(\mathrm{O}^{2-}\right)$ transported through the dense solid electrolyte. The non-electrochemical Boudouard reaction (3) can also contribute to the in situ formation of $\mathrm{CO}$, which then can be subsequently diffuse and electro-oxidize at anode three phase boundary (TPB) via reaction (4) [10].

$\mathrm{C}+2 \mathrm{O}^{2-} \rightarrow \mathrm{CO}_{2}+4 \mathrm{e}^{-}$

$\mathrm{C}+\mathrm{O}^{2-} \rightarrow \mathrm{CO}+2 \mathrm{e}^{-}$

$\mathrm{CO}_{2}+\mathrm{C} \rightarrow 2 \mathrm{CO}$

$\mathrm{CO}+\mathrm{O}^{2-} \rightarrow \mathrm{CO}_{2}+2 \mathrm{e}^{-}$

The carbon delivery to the anode TBP can be significantly improved by the infusion of a molten carbonates eutectic mixture into the carbon feedstock (Hybrid Carbon Fuel Cell, HCFC), enhancing the fluidity of solid fuel. In the presence of carbonates, the following stoichiometries, along with reactions (1)-(4), can be simultaneously carried out at anode [11-14]:

$\mathrm{C}+2 \mathrm{CO}_{3}{ }^{2-} \rightarrow 3 \mathrm{CO}_{2}+4 \mathrm{e}^{-}$

$\mathrm{C}+\mathrm{CO}_{3}{ }^{2-} \rightarrow \mathrm{CO}+\mathrm{CO}_{2}+2 \mathrm{e}^{-}$

$2 \mathrm{C}+\mathrm{CO}_{3}{ }^{2-} \rightarrow 3 \mathrm{CO}+2 \mathrm{e}^{-}$ 
Various carbonaceous feedstock have been examined as fuels in DCFCs to investigate their electrochemical reactivity. It has been revealed that their physicochemical characteristics notably affect the achieved DCFC performance [10,15-20]. For instance, the carbon and volatile matter contents as well as the structure disorder greatly enhanced the power output, whereas ash and sulfur contents have a detrimental effect on cell characteristics [15-20]. In this regard, acid and heat treatment are usually applied to modify the fuel characteristics and consequently the DCFC performance.

In the present communication, the effect of heat pretreatment on feedstock physicochemical characteristics and DCFC performance is investigated. Several parameters related to cell temperature $\left(700-800{ }^{\circ} \mathrm{C}\right)$, purging gas type $\left(\mathrm{He}\right.$ or $\left.\mathrm{CO}_{2}\right)$ and molten carbonates infusion into the carbon feedstock were also examined. Lignite, a coal of particular importance for many countries economy, is employed as fuel.

\section{MATERIALS AND METHODS}

\subsection{Materials synthesis}

The wet impregnation method was used in order to prepare the anode electrode, $20 \mathrm{wt} \% \mathrm{Co} / \mathrm{CeO}_{2}$ [19]. The $\mathrm{Ce}\left(\mathrm{NO}_{3}\right)_{3} \cdot 6 \mathrm{H}_{2} \mathrm{O}$ precursor (99\%, Sigma-Aldrich) was initially dissolved in distilled water and heated to $125^{\circ} \mathrm{C}$, under stirring, till all the water evaporated. The resulting sample was dried for $16 \mathrm{~h}$ at $110{ }^{\circ} \mathrm{C}$, and then calcined for $2 \mathrm{~h}$ at $600{ }^{\circ} \mathrm{C}$. A stoichiometric quantity of $\mathrm{Co}\left(\mathrm{NO}_{3}\right)_{2} \cdot 6 \mathrm{H}_{2} \mathrm{O}\left(99 \%\right.$, Sigma-Aldrich) precursor was then impregnated onto the calcined $\mathrm{CeO}_{2}$. The drying and calcination procedures in this step were identical to that described for the ceria support.

\subsection{Fuel characterization}

In the present study lignite coal was employed as the main feedstock. To investigate the impact of pre-treatment on DCFC characteristics, the pristine lignite (LG) was subjected to three different thermal treatment procedures under pure He atmosphere $\left(30 \mathrm{~cm}^{3} / \mathrm{min}\right)$ : a) at $200{ }^{\circ} \mathrm{C}$ overnight (LG200), b) at $500{ }^{\circ} \mathrm{C}$ (LG500) and c) at $800{ }^{\circ} \mathrm{C}$ (LG800) for $1 \mathrm{~h}$. The obtained samples were chemically analyzed by means of elemental analysis in LECO CHNS-932 and LECO VTF-9000 analyzers. Proximate analysis was carried out using the LECO TGA-601 equipment. Surface functionalities were also characterized by Fourier transform infrared spectroscopy (FTIR) in a Nicolet FTIR 8700 with the diffuse reflectance module Smart Collector. A high-sensitivity detector MCT-A 
of mercury cadmium telluride was used. The data were recorded between $4000-650 \mathrm{~cm}^{-1}$, using 100 scans and a resolution of $4 \mathrm{~cm}^{-1}$. The carbonaceous structure of the samples was characterised by means of XRD and Raman spectroscopy. X-Ray diffractograms were acquired in a Bruker D8 powder diffractometer equipped with a monochromatic $\mathrm{Cu}-\mathrm{K}_{\alpha} \mathrm{X}$-ray source and an internal standard of Silicon powder. Diffraction data were collected by step scanning with a step size of $0.02^{\circ}$ in the range of $5-90^{\circ}$, with an interval of $2 \mathrm{~s}$ between steps. The Raman spectroscopy analyses were carried out in a labRam HRUV 800 using JYV-Jobin Yvon equipment and an argon laser CDPS532M $532 \mathrm{~nm}$ at $24.3 \mathrm{~mW}$. Finally, the reactivity of the samples was determined by thermogravimetric (TG) analysis. Samples were heated up to $1000{ }^{\circ} \mathrm{C}$ with a rate of $10{ }^{\circ} \mathrm{C} / \mathrm{min}$ in a thermobalance (Q5000 IR, TA Instruments). The weight loss profile was recorded with increasing temperature, under both inert $\left(\mathrm{N}_{2}\right)$ and reactive $\left(\mathrm{CO}_{2}\right)$ atmosphere at a constant flow rate of 20 $\mathrm{cm}^{3} / \mathrm{min}$.

\subsection{DCFC fabrication and cell testing}

The fuel cell experiments were performed in a reactor cell consisting of an YSZ tube (CERECO) with $1.2 \mathrm{~mm}$ thickness, closed flat at its bottom end [18,19]. The cathode was deposited on the outside wall of the YSZ tube, prepared from a silver paste (05X Metallo-organic AG RESINATE) after calcination for $2 \mathrm{~h}$ at $850{ }^{\circ} \mathrm{C}$ in stagnant air, with a heating rate of $4{ }^{\circ} \mathrm{C} / \mathrm{min}$. The anode was prepared from a $\mathrm{Co} / \mathrm{CeO}_{2}$ powder, mixed with ethylene glycol at a 1:2 weight ratio [19]. The resulted solution was heated at about $200{ }^{\circ} \mathrm{C}$ and stirred at $400 \mathrm{rpm}$ until half of its volume was evaporated. Then the viscous suspension was deposited, by applying consecutive thin films with a paintbrush, on the inside bottom wall of the YSZ tube. The calcination procedure involved heating, under atmospheric air, to $850{ }^{\circ} \mathrm{C}$ for $2 \mathrm{~h}$. After calcination, the cell was cooled down to $200{ }^{\circ} \mathrm{C}$, where the anode was reduced in a flow of $30 \mathrm{~cm}^{3} / \mathrm{min}$ of $\mathrm{H}_{2}(100 \mathrm{vol} . \%)$ for $2 \mathrm{~h}$. In all cases, the amount of the deposited film was equal to $115 \mathrm{mg}$, resulting in an apparent electrode area of 1.7 $\mathrm{cm}^{2}$.

The electrochemical measurements were carried out in the temperature range of $700-800{ }^{\circ} \mathrm{C}$, at atmospheric pressure. In each experiment the cell is loaded either with bare carbon (800 $\mathrm{mg})$ or a carbon/carbonate mixture at a 4:1 weight ratio [18]. Pure $\mathrm{He}$ or $\mathrm{CO}_{2}$ (99.999\% purity, Air Liquide) was employed as purging gas, whereas the cathode was always exposed to atmospheric air. The flow rate of carrier gas was controlled by mass flow meters (Tylan FM 360) and equaled to 30 $\mathrm{cm}^{3} / \mathrm{min}$. The cell voltage and developed electrical current were monitored by means of digital 
multi-meters (RE60-69) and the external resistive load was controlled by a resistance box (Time Electronics 1051). The electrochemical impedance spectra were obtained under open circuit conditions in the frequency range between $0.1 \mathrm{~Hz}$ and $1 \mathrm{MHz}$ with an amplitude of $30 \mathrm{mV}$ RMS, using the Versa Stat 4 electrochemical workstation by Princeton Applied Research and the corresponding software (Versa Studio) for data processing. Analysis of the effluents was performed by an on-line Gas Chromatograph (SRI 8610B) equipped with a Molecular Sieve 5A and a Porapak Q columns.

\section{RESULTS AND DISCUSSION}

\subsection{Characterization of lignite fuel samples}

In Table 1 the proximate and ultimate analysis of the different heat treated lignite samples is depicted. It is obvious that upon increasing the temperature of heat treatment the carbon content and fixed carbon are monotonically increased, whereas the volatile matter, moisture, sulfur and oxygen contents are decreased due to the loss of volatiles.

Table 1: Proximate and ultimate analysis of the fuel samples

\begin{tabular}{|c|c|c|c|c|c|c|c|c|c|}
\hline \multirow[t]{2}{*}{ FUELS } & \multicolumn{4}{|c|}{ Proximate Analysis (wt.\%) } & \multicolumn{5}{|c|}{ Ultimate Analysis (wt.\%, dry ash free basis) } \\
\hline & $\mathbf{F C}^{\mathbf{a}}$ & $\mathbf{V} \mathbf{M}^{\mathbf{a}}$ & $\mathbf{A s h}^{\mathbf{a}}$ & Moisture & $\mathbf{C}$ & $\mathbf{H}$ & $\mathbf{N}$ & $\mathbf{S}$ & $\mathbf{O}$ \\
\hline $\mathbf{L G}$ & 28.1 & 42.6 & 17.6 & 11.7 & 55.1 & 3.6 & 0.9 & 0.8 & 39.7 \\
\hline LG200 & 39.4 & 42.6 & 12.5 & 5.5 & 62.9 & 4.3 & 0.9 & 0.6 & 31.3 \\
\hline LG500 & 49.3 & 28.3 & 19.0 & 3.4 & 73.7 & 3.4 & 1.2 & 0.3 & 21.4 \\
\hline LG800 & 63.1 & 12.8 & 21.7 & 2.4 & 87.2 & 1.4 & 1.0 & 0.3 & 10.1 \\
\hline
\end{tabular}

${ }^{a}$ dry basis

The heat treatment removed most of the labile compounds in the pristine coal, notably affecting the carbonaceous structure. XRD spectra (data not shown) revealed very similar structure for all examined samples, showing a similar characteristic peak of the carbonaceous structure at ca $25^{\circ}$, plane (002), although not very well defined as it is expected for lignite samples. To gain further insight into the impact of heat treatment on the crystallite structure, the Raman spectra of original and thermally-treated Lignite samples were acquired (Fig. 1). All samples showed the characteristic $\mathrm{D}$ and $\mathrm{G}$ bands at ca. 1350 and $1600 \mathrm{~cm}^{-1}$, respectively. The ratio of the intensity of $\mathrm{D}$ and $\mathrm{G}$ bands $\left(\mathrm{I}_{\mathrm{D}} / \mathrm{I}_{\mathrm{G}}\right)$ is usually considered to evaluate the degree of disorder of the carbonaceous structure. This 
ratio, in general, increases with the degree of disorder in graphitic materials. In the present case, the $\mathrm{I}_{\mathrm{D}} / \mathrm{I}_{\mathrm{G}}$ ratio is decreased due to the elimination of volatiles during heat treatment, presenting values equal to $0.87,0.85,0.80$ and 0.76 for LG, LG200, LG500 and LG800, respectively. The latter demonstrates the increase of ordered structure upon increasing the pre-treatment temperature.

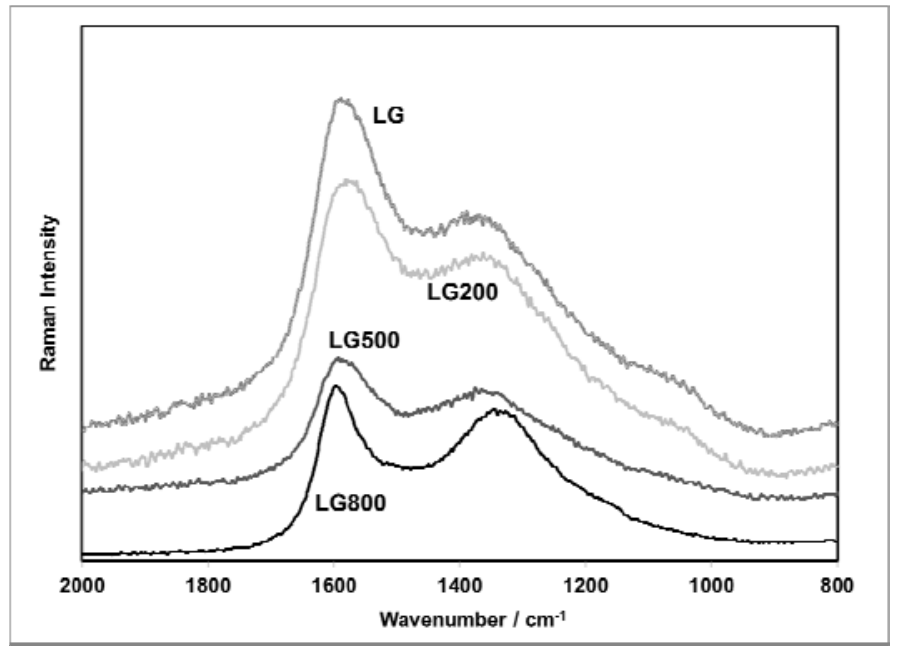

Figure 1. Raman characterization of the pristine and heat treated LG samples.

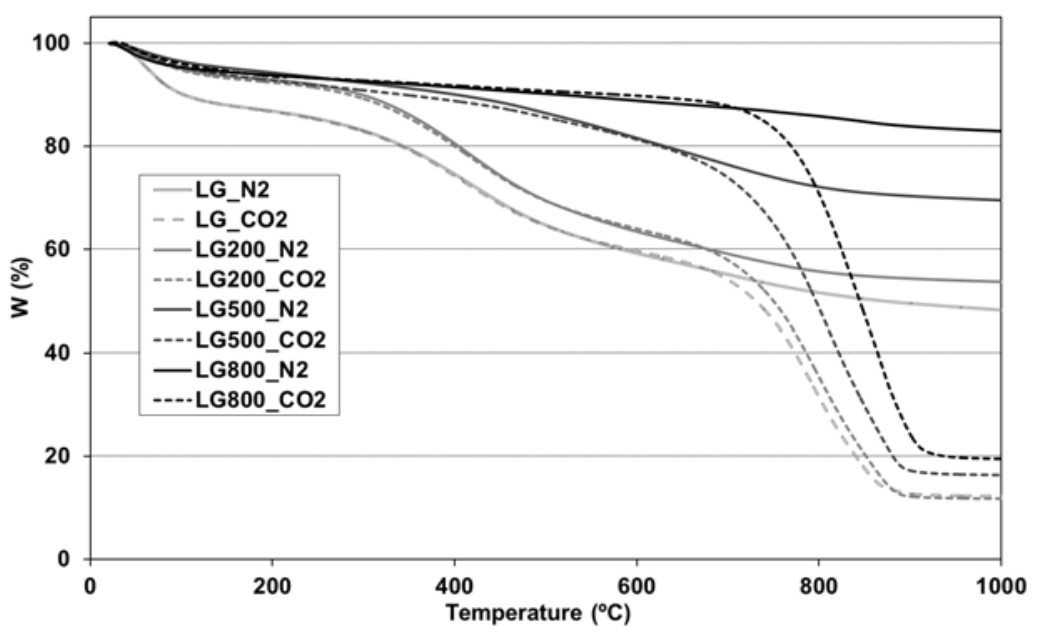

Figure 2. TGA profiles of the pristine and heat treated LG samples under inert $\left(\mathrm{N}_{2}\right)$ and reactive $\left(\mathrm{CO}_{2}\right)$ atmosphere.

The main effect of the heat treatment on the LG samples is the elimination of the more labile surface compounds, as revealed by FTIR experiments (data not shown). As a result the carbon content of the heat treated samples increases upon pretreatment and therefore their reactivity is expected to be increased. This can be corroborated by the thermogravimetric (TG) analysis performed in inert $\left(\mathrm{N}_{2}\right)$ and reactive $\left(\mathrm{CO}_{2}\right)$ atmosphere (Fig. 2). Indeed, all samples present a similar weight loss profile under both $\mathrm{N}_{2}$ and $\mathrm{CO}_{2}$ flow up to a specific temperature, where the sample starts to interact with $\mathrm{CO}_{2}$. At lower temperatures the weight loss detected is due only to the effect 
of temperature on the breakage of the labile compounds. The LG sample presents the higher weight loss due to the high volatile content of this sample. The higher the heating temperature used, the lower the remaining volatiles in the sample and thus the lower the weight loss in the TGA- $\mathrm{N}_{2}$ profiles. However, it is worth to note that under $\mathrm{CO}_{2}$ flow the weight loss due to the reaction of carbon with $\mathrm{CO}_{2}$ (at temperatures higher than ca. $700^{\circ} \mathrm{C}$, where the reverse Boudouard reaction is favored), follows the order: LG800>LG500>LG200>LG, in complete agreement with their carbon content (Table 1).

\subsection{DCFC performance}

\subsubsection{Effect of LG heat treatment on DCFC performance under He flow}

Figure 3 shows the impact of lignite heat treatment on DCFC performance at 700, 750 and $800{ }^{\circ} \mathrm{C}$ under He flow. The best performance is obtained by the LG800 which demonstrates a maximum power density of $6.6,11.4$ and $14.9 \mathrm{~mW} . \mathrm{cm}^{-2}$ at 700,750 and $800{ }^{\circ} \mathrm{C}$, respectively. Under the same cell temperatures lower maximum power densities are achieved for the rest samples. The corresponding maximum power density values for LG, LG200 and LG500 at $800{ }^{\circ} \mathrm{C}$ were equal to 11.4, 12.2 and $13.2 \mathrm{~mW} . \mathrm{cm}^{-2}$, respectively. The optimum performance obtained with the LG800 sample indicates the beneficial effect of the thermal treatment on cell performance, which based on the proximate/ultimate analysis leads to higher carbon content and lower sulfur concentration. Thus, the following order of performance is recorded: LG800 > LG500 > LG200 > LG. Concerning the developed Open Circuit Voltage (OCV), a clear increase is observed upon increasing cell temperature for all samples. For instance, OCV absolute values of 1007, 1027 and $1098 \mathrm{mV}$ are recorded at 700, 750 and $800{ }^{\circ} \mathrm{C}$, respectively, for LG800 sample. At $800{ }^{\circ} \mathrm{C}$ the developed absolute $\mathrm{OCV}$ is increasing with the fuel pre-treatment temperature, according to the observed cell performance. At lower temperatures, the reverse order was recorded, implying the combining effect of fuel characteristics and cell temperature on $\mathrm{OCV}$, as discussed in the sequence.

The corresponding open circuit AC impedance spectra at 700, 750 and $800{ }^{\circ} \mathrm{C}$, are also depicted in Figure 4. They are comprised of a small high frequency (HF) arc, overlapped with a large low frequency (LF) arc. In all cases, the size of both arcs, which indicates the electrode resistance, is notably decreased with the cell temperature and the degree of heat treatment. More specifically, both the ohmic (intercept of the high frequency arc with the real axis) and electrode resistances are decreased in the order of LG800 $<$ LG500 $<$ LG200 $<$ LG as well as upon increasing cell temperature, in perfect agreement with the observed DCFC performance. The ohmic resistance is 
substantially decreased by increasing the cell temperature, while a moderate decrease is observed as the treatment temperature increases. Ohmic resistance values of $16.9,12.0$ and $8.0 \Omega \mathrm{cm}^{2}$ are recorded for LG800 sample at 700, 750 and $800{ }^{\circ} \mathrm{C}$, respectively, indicating the beneficial impact of cell temperature. The corresponding values for the LG, LG200 and LG500 at $800{ }^{\circ} \mathrm{C}$, are equal to 10.6, 9.0 and $8.9 \Omega \mathrm{cm}^{2}$, respectively, reflecting the lower cell voltage - current density slopes observed upon increasing the temperature of pretreatment.
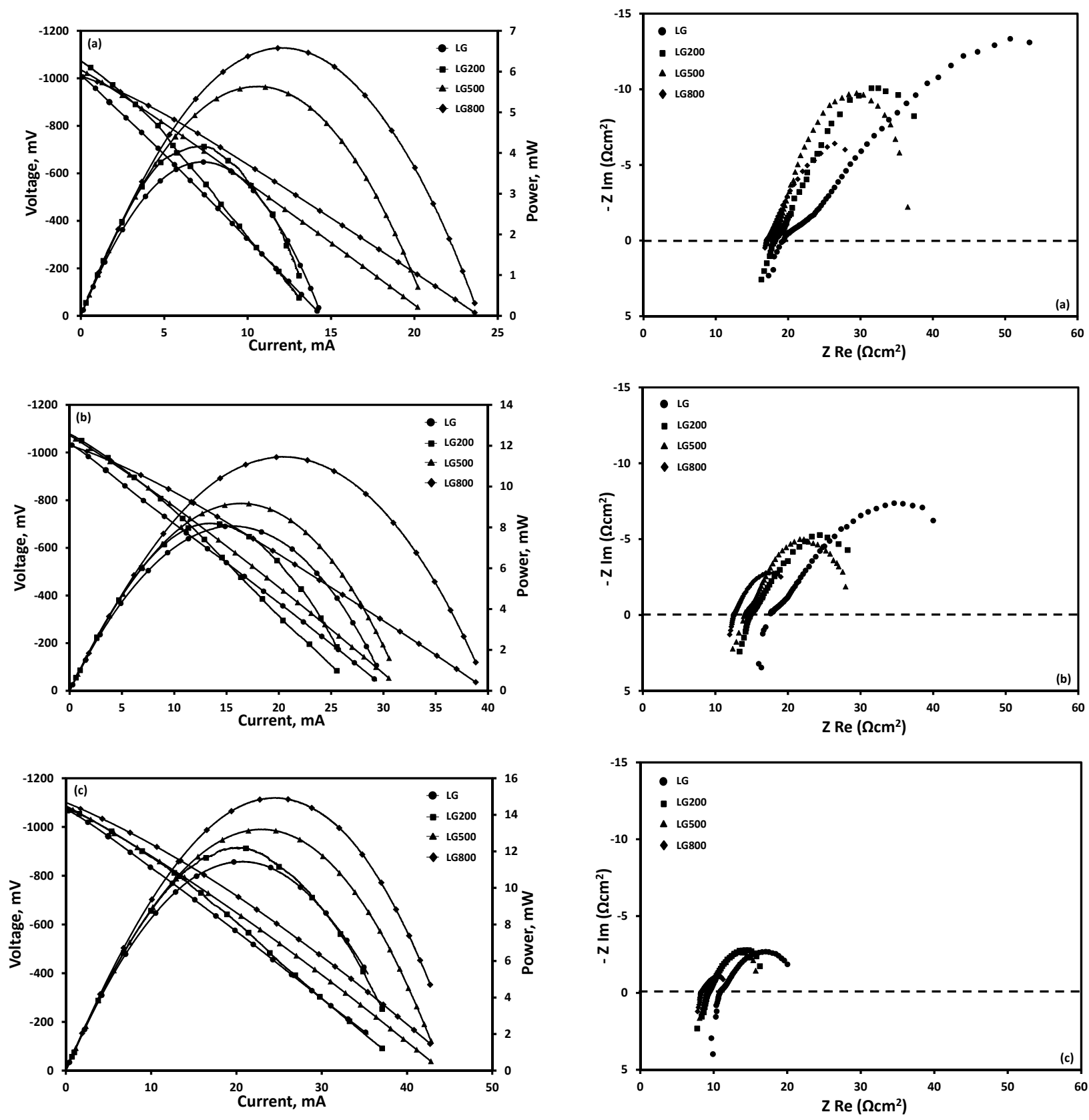

Figure 3: Effect of lignite heat treatment on DCFC performance and the corresponding AC impedance spectra at a) $700{ }^{\circ} \mathrm{C}$, b) $750{ }^{\circ} \mathrm{C}$ and c) $800{ }^{\circ} \mathrm{C}$, by employing pure He as carrier gas. Feedstock: $800 \mathrm{mg}$ lignite; Carrier gas (100 vol.\% He) flow $=30 \mathrm{~cm}^{3} / \mathrm{min}$. 
In addition, the electrode resistance follows a similar trend, which is notably influenced by the cell temperature and the heat treatment temperature. Electrode resistance values of 19.3, 10.3 and 4.3 $\Omega \mathrm{cm}^{2}$, are observed for LG800 at 700, 750 and $800{ }^{\circ} \mathrm{C}$, respectively, while the corresponding values for LG, LG200 and LG500 at $800{ }^{\circ} \mathrm{C}$ are equal to $11.5,8.8$ and $6.7 \Omega \mathrm{cm}^{2}$, respectively. Based on the pseudo-capacitance values of both arcs, which are falling in the order of $10^{-4}-10^{-6} \mathrm{~F} / \mathrm{cm}^{2}$ for the $\mathrm{HF}$ arc and $10^{-2}-10^{-1} \mathrm{~F} / \mathrm{cm}^{2}$ for the LF arc, it can be safely assumed that the HF arc is attributed to charge transfer processes, while the LF arc clearly reflects the associated mass transfer limitations. The size of the HF arc decreases with the increase in cell and heat treatment temperatures, implying an improvement in the electrochemical reactivity of the LG samples. More notably, the size of the LF arc also follows a similar behavior denoting better mass transport characteristics.

\subsubsection{Effect of $\mathrm{LG}$ heat treatment on DCFC performance under $\mathrm{CO}_{2}$ flow}

The corresponding results obtained under $\mathrm{CO}_{2}$ flow are depicted in Fig. 4. By comparing these results with those obtained under He flow (Fig. 3) the pronounced effect of $\mathrm{CO}_{2}$ as purging gas on DCFC performance is revealed. The beneficial impact of $\mathrm{CO}_{2}$ is more intense at low cell temperatures and for the less reactive samples. For instance, a maximum power density of 4.9, 9.3 and $13.1 \mathrm{~mW} / \mathrm{cm}^{2}$ is achieved for LG sample under $\mathrm{CO}_{2}$ flow at 700,750 and $800{ }^{\circ} \mathrm{C}$, respectively, as compared to the corresponding values of $3.8,8.0$ and $11.4 \mathrm{~mW} / \mathrm{cm}^{2}$ when $\mathrm{He}$ is employed as carrier gas. However, the order of DCFC performance is remained unchanged under $\mathrm{CO}_{2}$ flow, i.e.: LG800 > LG500 > LG200 > LG, revealing the close correlation between samples characteristics and power output, as further discussed in the sequence. The corresponding OCV absolute values are increasing with cell temperature, being, however, lower to that obtained under He flow (Figure 3). Moreover, the OCV is, in general, increased with the pre-treatment temperature.

As far as the corresponding AC impedance spectra concern, the ohmic resistance decreases from 17.2 to $7.1 \Omega \mathrm{cm}^{2}$ upon increasing the cell temperature from 700 to $800{ }^{\circ} \mathrm{C}$ for the LG feedstock, while the corresponding values under He flow were equal to 17.6 and $10.6 \Omega \mathrm{cm}^{2}$, respectively. A similar behavior is observed for all other heat treated lignite samples although the differences between the samples are rather minor, indicating that the temperature of heat treatment slightly affects the ohmic resistance. The observed decrease in ohmic resistance upon increasing cell temperature and employing $\mathrm{CO}_{2}$ as carrier gas, can be assigned to the in situ formed $\mathrm{CO}$ via the reverse Boudouard reaction, which leads to a gradual reduction of $\mathrm{Co} / \mathrm{CeO}_{2}$ anode composite, as has been already verified by 4-probe conductivity measurements [19]. 

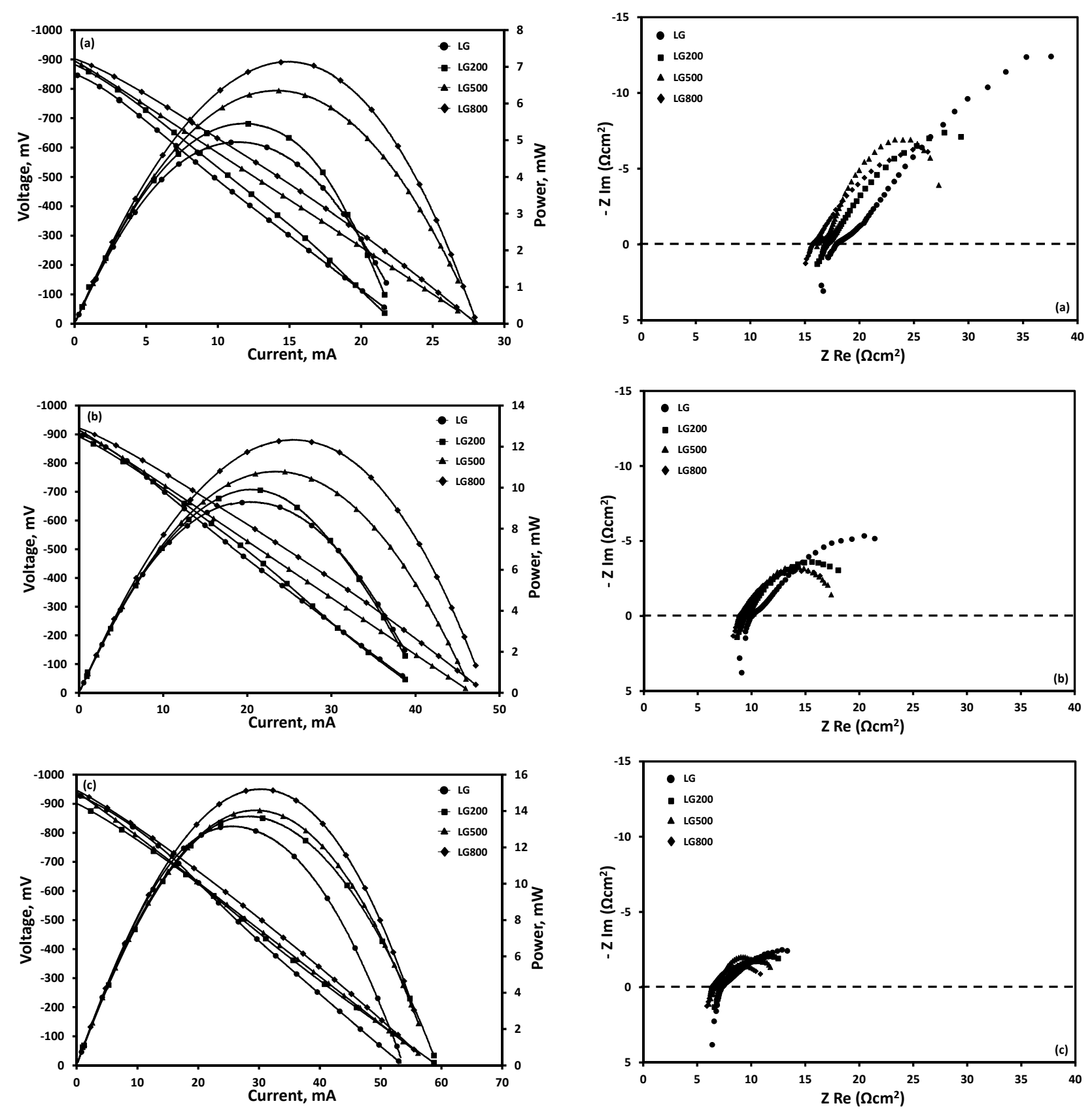

Figure 4: Effect of lignite heat treatment on DCFC performance and the corresponding AC impedance spectra at a) $700{ }^{\circ} \mathrm{C}$, b) $750{ }^{\circ} \mathrm{C}$ and c) $800{ }^{\circ} \mathrm{C}$ by employing pure $\mathrm{CO}_{2}$ as carrier gas. Feedstock: $800 \mathrm{mg}$ lignite; Carrier gas (100 vol. $\left.\% \mathrm{CO}_{2}\right)$ flow $=30 \mathrm{~cm}^{3} / \mathrm{min}$.

The electrode resistance is notably influenced by the cell temperature, the employed carrier gas and the heat treatment. For the LG800 feedstock, the electrode resistance is decreased from 18.6 to 9.8 and $4.9 \Omega \mathrm{cm}^{2}$ as the cell temperature increased from 700 to 750 and $800{ }^{\circ} \mathrm{C}$, respectively. A similar trend is observed upon cell temperature increase for the rest samples. Moreover, the electrode resistance is affected by the purging gas type $\left(\mathrm{He}\right.$ or $\left.\mathrm{CO}_{2}\right)$ and the sample pre-treatment. For the less 
reactive samples, i.e. LG and LG200, the electrode resistance is significantly decreased by employing $\mathrm{CO}_{2}$ instead of $\mathrm{He}$; at $700^{\circ} \mathrm{C}$, from 53.4 to $39.6 \Omega \mathrm{cm}^{2}$ for $\mathrm{LG}$ sample and from 40.0 to $20.9 \Omega \mathrm{cm}^{2}$ for LG200 sample. For the more reactive samples, i.e. LG500 and LG800, the differences in electrode resistance upon purging gas switching are more obvious at lower cell temperatures. Finally, the electrode resistance is in general decreased with the increase of pretreatment temperature; at $800^{\circ} \mathrm{C}$ the electrode resistance is equal to $8.3,8.2,7.2$ and $4.9 \Omega \mathrm{cm}^{2}$, for the LG, LG200, LG500 and LG800, respectively.

The .pronounced effect of $\mathrm{CO}_{2}$ as purging gas can be mainly interpreted on the basis of $\mathrm{CO}_{2}$ impact on the CO formation via the reverse Boudouard reaction. This in situ formed CO, can be faster electro-oxidized and diffused at TPB, as compared to solid carbon, resulting in lower activation and concentration overpotentials and thus to improved electrochemical performance.

\subsubsection{Effect of LG heat treatment on cell performance in the presence of carbonates under $\mathrm{CO}_{2}$ flow (Hybrid Carbon Fuel Cell, HCFC)}

An eutectic mixture of carbonates $\left(62 \mathrm{~mol} \% \mathrm{Li}_{2} \mathrm{CO}_{3}+38 \mathrm{~mol}_{0} \mathrm{~K}_{2} \mathrm{CO}_{3}\right)$ was admixed with the lignite samples at a carbon/carbonate weight ratio of $4: 1$, in order to investigate the impact of carbonates infusion on cell characteristics at 700, 750 and $800{ }^{\circ} \mathrm{C}$ under $\mathrm{CO}_{2}$ flow (Figure 5). A similar order (LG < LG200 < LG500 < LG800) in the achieved electrochemical performance is obtained under the hybrid mode of operation. The pronounced effect of carbonates is evident in the whole temperature range investigated and for all studied feedstock. Specifically, the addition of carbonates led to an obvious increment of the achieved maximum power densities, from $70 \%$ up to $100 \%$, as compared to that obtained in the absence of carbonates, depending on the cell temperature and on the reactivity of the lignite samples. Higher absolute OCV values are developed in the presence of carbonates, which are increased with cell temperature, as also observed in DCFC mode of operation under $\mathrm{CO}_{2}$ flow. Moreover, a decrease on OCV was recorded upon increasing the pretreatment temperature. However, the $\mathrm{OCV}$ values obtained under $\mathrm{CO}_{2}$ flow, both in $\mathrm{DCFC}$ and HCFC mode, are always lower as compared to the corresponding ones under He flow. On the light of the aforementioned aspects, the differences between OCV values and their deviation from the theoretical predicted OCV (ca. 1.0 V) in all examined cases can be ascribed to the complex chemical and charge transfer reaction network taking place at anode. In view of this fact, it has been well established in the relevant studies that the developed OCV can be significantly altered by fuels 
physicochemical characteristics, carrier gas type and operating conditions as well as by the presence of carbonates [12,13,18-20]. All these factors strongly affect the homogeneous/surface chemical and charge transfer reactions at the anode chamber, determining the anode gas composition and in consequence the developed OCV.
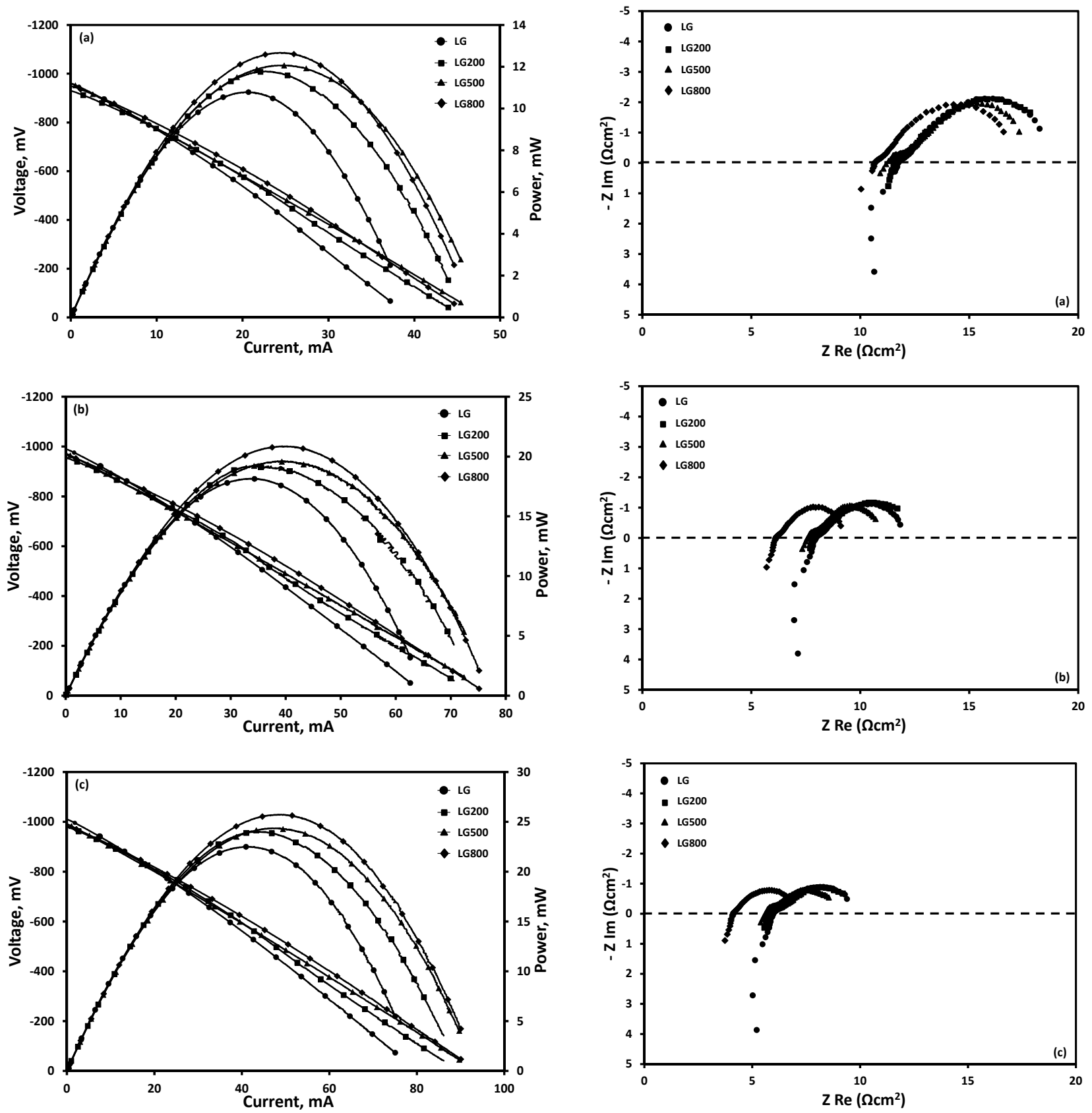

Figure 5: Effect of lignite heat treatment on DCFC performance and the corresponding AC impedance spectra at a) $700{ }^{\circ} \mathrm{C}$, b) $750{ }^{\circ} \mathrm{C}$ and c) $800{ }^{\circ} \mathrm{C}$, in the co-presence of carbonates employing pure $\mathrm{CO}_{2}$ as carrier gas. Feedstock: $800 \mathrm{mg}$ lignite and $200 \mathrm{mg}$ Carbonates; Carrier gas (100 vol. $\% \mathrm{CO}_{2}$ ) flow $=30 \mathrm{~cm}^{3} / \mathrm{min}$. 
The open circuit AC impedance spectra (Fig. 5) are in perfect agreement with the observed cell characteristics. The ohmic resistance is significantly decreased with the addition of carbonates in the feedstock, e.g., from 15.3, 8.2 and $6.3 \Omega . \mathrm{cm}^{2}$ to $10.6,7.9$ and $4.1 \Omega \mathrm{cm}^{2}$ at 700,750 and $800{ }^{\circ} \mathrm{C}$, respectively, for LG800 sample. This beneficial effect of carbonates is more pronounced at lower temperatures. In addition, a clear improvement on electrode resistance is obtained for all lignite samples when the carbonates are admixed to the feedstock and as the cell temperature increases, reflecting the obtained DCFC performance. This enhancement is clearly depicted to both charge transfer (HF arc) and mass transport (LF arc) contributions. The carbonates facilitate the diffusion of solid fuels, contributing also to an additional amount of formed CO through the reactions (5)-(7). However, there are no obvious differences between the various heat treated lignite samples. More specifically, the electrode resistance decreases by carbonates infusion to LG800 feedstock from 18.6, 9.8 and $4.9 \Omega \mathrm{cm}^{2}$ to $6.7,4.2$ and $3.4 \Omega \mathrm{cm}^{2}$, at 700,750 and $800{ }^{\circ} \mathrm{C}$, respectively. The corresponding values in the presence of carbonates for LG, LG200 and LG500 are slightly higher compared to the LG800/carbonates mixture.

The obtained results clearly revealed that thermal treatment significantly modifies the physicochemical characteristics of lignite and consequently the achieved electrochemical performance. The increase in pre-treatment temperature results to an increase of carbon content, which is followed by a decrease in volatile matter, moisture and sulfur contents. On the other hand, Raman spectroscopy showed that pre-treatment leads to more ordered structures. Surface and porosity of heated samples was also evaluated, but no significant differences were recorded with the heat treatment, neither different optical texture was observed by SEM.

In closely related studies, it has been already shown that feedstock with high carbon and volatile matter contents result in higher power outputs, while the presence of sulfur and high ordered structures hinders the electrochemical reactivity $[5,17,18]$. Moreover, an almost linear correlation between the achieved power density and the $\mathrm{CO}$ formation rate was observed, reflecting the key role of in situ generated CO on the electrochemical performance via the well-known CO "shuttle" mechanism $[5,18]$. The latter, however, is mainly determined by the extent of reverse Boudouard reaction, which in turns is governed by the fuel characteristics (volatile matter, carbon, sulfur and ash contents, structure, porosity). Hence, based on the present findings, it could be argued that the clear increment in carbon content and decrease in sulfur concentration upon heat treatment counterbalanced the negative impact that could be induced by the decrease in volatile matter and 
increase in ash content. This explanation is in agreement with the reactivity of the investigated samples toward $\mathrm{CO}_{2}$ (Figure 2); the weight loss due to the reaction of carbon with $\mathrm{CO}_{2}$ (via the reverse Boudouard reaction) follows the order LG800 $>$ LG500 $>$ LG200 $>$ LG, in complete agreement with their carbon content.

Finally, the low power densities achieved in the present work, under both DCFC and HCFC mode of operation, should be mentioned. This can be mainly assigned to the ohmic losses derived by the high electrolyte thickness (about $1.2 \mathrm{~mm}$ ) and the anodic and cathodic electrode/electrolyte interfacial polarizations, as revealed by the corresponding impedance spectroscopy studies. Hence, further technological advancements related to cell fabrication need to be developed by employing thinner electrolyte membranes in combination to state-of-the art electrode/electrolyte configurations, in order to minimize the associated polarization losses and improve the performance. In this direction, high power densities, up to $878 \mathrm{~mW} / \mathrm{cm}^{2}$ at $750{ }^{\circ} \mathrm{C}$, have been recently obtained in an anode supported HCFC, employing pyrolysed medium density fibreboard (PMDF) as feedstock, Ni/YSZ cermet as anode, YSZ as electrolyte (ca. $5 \mu \mathrm{m}$ thickness), $\mathrm{La}_{0.6} \mathrm{Sr}_{0.4} \mathrm{CoO}_{3-\delta}$ as cathode and $\mathrm{Ce}_{0.9} \mathrm{Gd}_{0.1} \mathrm{O}_{2}$ as interlayer between the cathode (LSC) and the electrolyte (YSZ) [21].

\section{CONCLUSIONS}

The effect of lignite heat treatment on the electrochemical performance of a Direct Carbon Fuel Cell (DCFC) was examined in the present study. The results confirmed that the thermal process of lignite has a pronounced effect on DCFC characteristics. Upon coupling the characterization studies with the fuel cell and AC impedance spectroscopy measurements, insights into the role of each process and physicochemical parameter were revealed. Higher power output was achieved when switching from an inert atmosphere to $\mathrm{CO}_{2}$, while the addition of carbonates almost doubled the DCFC performance, especially at lower temperatures. These improvements were assigned to the surplus CO formed in situ via the reverse Boudouard reaction, which is favored at reactive atmospheres and in the presence of carbonates. This additional $\mathrm{CO}$ bypasses the activation and concentration overpotentials of lignite, since it present faster electro-oxidation kinetics and better diffusion compared to solid feedstock. The heat treatment increases the carbon content and the condensed carbon structures of lignite samples, while it decreases the volatile matter, moisture, sulfur and oxygen contents. Taking into account the already acknowledged effects of the aforementioned parameters on DCFC operation it can be assumed that the influence of increased carbon content and 
lower sulfur concentrations have a stronger impact on cell performance compared to the influence of the decreased volatile matter content and the increase of ordered structures.

\section{Acknowledgements}

The authors would like to acknowledge financial support from the European project "Efficient Conversion of Coal to Electricity - Direct Coal Fuel Cells", which is funded by the Research Fund for Carbon \& Steel (RFCR CT-2011-00004).

\section{RERERENCES}

[1] Badwal S.P.S. and Giddey S. The holy grail of carbon combustion-The Direct Carbon Fuel Cell Technology. Materials Forum 2010; 34:181-185.

[2] Desclaux P., Nurnberger S., Rzepka M., Stimming U. Investigation of direct carbon conversion at the surface of a YSZ electrolyte in a SOFC. International Journal of Hydrogen Energy 2011; 36:10278-10281.

[3] Rady A.C., Giddey S., Badwal S.P.S., Ladewing B.P. and Bhattacharya S. Review of fuels for direct carbon fuel cells. Energy Fuels 2012; 26:1471-1488.

[4] Cao D.X., Sun Y., Wang G.L. Direct carbon fuel cell: Fundamentals and recent developments. Journal of Power Sources 2007;167:250-257.

[5] Gür TM. Critical Review of Carbon Conversion in "Carbon Fuel Cells". Chemical Reviews 2013; 113:6179-6206.

[6] Zecevic S., Patton E.M., Parhami P. 2004. Carbon-air fuel cell without a reforming process. Carbon 2004; 42:1983-1993.

[7] Basu S. Recent Trends in Fuel Cell Science and Technology, Anamaya, New Delhi, 2007.

[8] Kurzweil, P. History | Fuel cells. In Encyclopedia of Electrochemical Power Sources; Jürgen, G., Ed.; Elsevier: Amsterdam, The Netherlands, 2009; pp 579-595.

[9] Giddey S, Badwal SPS, Kulkarni A, Munnings C. A Comprehensive Review of Direct Carbon Fuel Cell Technology. Progress in Energy and Combustion Science 2008; 38:360399.

[10] Chien A.C., Chuang S.S.C. Effect of gas flow rates and Boudouard reactions on the performance of $\mathrm{Ni} / \mathrm{YSZ}$ anode supported solid oxide fuel cells with solid carbon fuels. Journal of Power Sources 2011; 196:4719-4723.

[11] Nabae, Y., Pointon, K.D., Irvine, J.T.S. Ni/C slurries based on molten carbonates as a fuel for hybrid direct carbon fuel cells. Journal of Electrochemical Society 2009; 156:B716-B720. 
[12] Jiang, C., Irvine, J.T.S. Catalysis and oxidation of carbon in a hybrid direct carbon fuel cell. Journal of Power Sources 2011; 196:7318-7322.

[13] Nabae, Y., Pointon, K.D., Irvine, J.T.S. Electrochemical oxidation of solid carbon in hybrid DCFC with solid oxide and molten carbonate binary electrolyte. Energy \& Environnemental Science 2008; 1:148-155.

[14] Deleebeeck, L., Hansen, K.K. Hybrid direct carbon fuel cells and their reaction mechanisms-a review. Journal of Solid State Electrochemistry 2014; 18:861-882.

[15] Cherepy N.J., Krueger R., Fiet K.J., Jankowski A.F., Cooper J.F. Direct conversion of carbon fuels in a molten carbonate fuel cell. Journal of the Electrochemical Society 2005; 152:A80A87.

[16] Li X., Zhu Z., De Marco R., Bradley J., Dicks A. Evaluation of raw coals as fuels for direct carbon fuel cells. Journal of Power Sources 2010; 195:4051-4058.

[17] Vutetakis D.G., Skidmore D.R., Byker H.J. Electrochemical Oxidation of Molten CarbonateCoal Slurries. Journal of the Electrochemical Society 1987; 134:3027-3035.

[18] Kaklidis N., Kyriakou V., Garagounis I., Anerillas A., Menéndez J.A., Marnellos G.E., Konsolakis M. Effect of carbon type on the performance of a direct or hybrid carbon solid oxide fuel cell. RCS Advances 2014; 4:18792-18800.

[19] Kaklidis N., Garagounis I., Kyriakou V., Besikiotis V., Arenillas A., Menéndez J.A., Marnellos G.E., Konsolakis M. Direct utilization of Lignite coal in a $\mathrm{Co}-\mathrm{CeO}_{2} / \mathrm{YSZ} / \mathrm{Ag}$ solid oxide fuel cell. International Journal of Hydrogen Energy 2015; 40:14353-13363.

[20] Konsolakis M., Kaklidis N., Marnellos G.E., Zaharaki D., Komnitsas K. Assessment of biochar as feedstock in a direct carbon solid oxide fuel cell. RCS Advances 2015; 5: 7339973409.

[21] Jiang C., Ma J., Bonaccorso A.D., Irvine J.T.S. Demonstration of higher power, direct conversion of waste-derived carbon in a hybrid direct carbon fuel cell. Energy Environ. Sci. 2012; 5:6973-6980. 